\title{
Production and interaction of pastures and shelterbelts in the central North Island
}

\author{
M.F. HAWKE and J.D. TOMBLESON \\ AgResearch, PO Box 951, Rotorua \\ NZ Forest Research Institute, Private Bag 3020, Rotorua
}

\begin{abstract}
Many New Zealand farms contain shelterbelts which have generally been unmanaged, resulting in dubious shelter benefits and poor log values at harvest. The effect of a 6- and 7-row Pinus radiata shelterbelt on adjacent pasture production was monitored at Matea, Taupo during 1992193. Pasture production was measured at a range of distances parallel to the shelterbelts on both sides and on open pasture. A 15\% increase in pasture production was recorded at 0.7 tree height distance on both sides of the shelterbelts. There was also a gradual trend of increasing dry matter production as distance from the shelterbelts increased. However, on average, the sheltered zone produced slightly less dry matter than the open pasture. Increases in soil and herbage nutrient levels close to the shelterbelt suggest nutrient transfer by animals to the sheltered zones may have occurred. Shelterbelt tree growth was assessed and projected forward to maturity. Merchantable log volume at age 28 years was predicted to be $2300 \mathrm{~m}^{3} / \mathrm{km}$ of shelterbelt. Based on current log prices the 7-row shelterbelt was estimated at age 28 years to have a net value of $\$ 130000 / \mathrm{km}$.
\end{abstract}

Keywords: $\log$ value, nutrients, pasture production, pasture composition, Pinus radiata, shelter, shelterbelt, wood yields

\section{Introduction}

Shelterbelts have been planted for over 100 years, but they have generally been unmanaged (Chevasse 1982). Most New Zealand farms have shelterbelts and there is increasing interest from farmers in this system of agroforestry (Morey 1988).

Multiple-row shelterbelts are a feature of many regions throughout New Zealand, one of their objectives being a source of timber. Agricultural shelter benefits have been measured in a study by Radcliffe (1985) in Canterbury, which showed a positive pasture response to shelter. Sturrock (1972) defined the benefits of shelterbelts in terms of wind speed reduction for a wide range of designs, and farm survey data indicated that sheltered farms suffered reduced stock losses (Shelter Working Party Report 1982). Sturrock (1988) also highlighted an impressive list of functions for shelterbelts, including protection of soils, improving working conditions, increasing farm management options and conserving wildlife.

Previous pasture measurements parallel to single and double row Pinus radiata shelterbelts in the Rotoma and Waikato districts showed reductions in pasture yields compared with non-sheltered areas (Hawke 1992). Furthermore, at the Tikitere Agroforestry Research trial, near Rotorua, there was no evidence that pasture yields were improved under the range of final crop stockings of 100-400 stems/ha (Hawke 1991).

Although animal welfare issues have not been well researched in New Zealand, Holmes \& Sykes (1984) suggested that livestock would benefit from shelter and that the provision of shade enhances their welfare. Movement of stock into the shaded and sheltered areas of a shelterbelt can result in fertility transfer (Sturrock 1977), but Radcliffe (1985) commented that this had not occurred in the Canterbury study. Research into measuring shelter effects in New Zealand have been carried out on the leeward side only of the shelterbelt (Radcliffe 1985).

Studies of shelterbelt tree and log characteristics located in the central North Island and Canterbury regions (Tombleson \& Inglis 1986) showed that the middle rows resembled a close-spaced plantation while the edge trees were considerably larger and contained large branches. These studies also showed that with the exception of branch size, shelterbelt-grown trees have similar tree and $\log$ characteristics to plantationgrown trees and as such could be modelled using models developed for plantation-grown trees.

\section{Site details and management}

The two radiata pine shelterbelts were located on Kotara Land Corporation Block, Matea, $32 \mathrm{~km}$ south east of Taupo.

The soil type was classified as Kaingaroa Sand (DSIR 1954) and the climate described as winter cold, summer moist with an annual rainfall of 1700-1800 
$\mathrm{mm}$. Altitude was $690 \mathrm{~m}$ asl. The area has been in improved pasture for approximately 25 years and consisted of ryegrass, white clover, poa species, browntop, Yorkshire fog, cocksfoot and sweet vernal. Rotational grazing was with sheep and beef cattle.

The two shelterbelts ( 1 x 6 row and $1 \times 7$ row $)$ were planted in 1982 in a north east, south west orientation. They were $1 \mathrm{~km}$ apart and each shelterbelt was over $600 \mathrm{~m}$ long on flat terrain. Both shelterbelts were approximately $15 \mathrm{~m}$ tall at age 10 and had been pruned to a height of $1.6 \mathrm{~m}$. The fence to fence width of both shelterbelts was $21 \mathrm{~m}$. Tree spacing was $2 \mathrm{x}$ $3 \mathrm{~m}$ and $2 \times 3.5 \mathrm{~m}$ in the 6- and 7-row shelterbelts respectively. Merchantable log volume and value for the 7-row shelterbelt was calculated using STANDPAK (Whiteside 1989) with estimates of yield and value expressed on a $1 \mathrm{~km}$ of shelterbelt unit area (see Appendix 1 for details). The shelterbelt had a tree stocking of 3500 stems $/ \mathrm{km}$.

Two pasture cages $(60 \mathrm{~cm} \times 30 \mathrm{~cm})$ were located on trimmed spots on 3 September 1992 at the following distances on both sides of the shelterbelts: 5, 10, 20, $40,80,120,160$ and $200 \mathrm{~m}$. The $200 \mathrm{~m}$ spot at $13 \mathrm{x}$ tree height (h) on both sides of the shelterbelts was considered to be equivalent to an "open" pasture situation, i.e., not influenced by the shelterbelt (Sturrock 1972).

Pasture growth was measured by taking quadrat samples $(47 \mathrm{~cm} \times 25.4 \mathrm{~cm})$ from within each cage (Piggott 1986) with electric shears on 4 occasions over a 7-month period from 3 September 1992 to 25 March 1993. Dry matter production was calculated from each pair of samples. New areas were trimmed at each cutting time and the cages placed on them. Pine needles were discarded.

On the first production cut, herbage and soil samples were taken for chemical analysis (Comforth \& Sinclair 1984). Pasture samples were also taken for herbage dissection analysis at the first cut. Samples were bulked from the two shelterbelts for each side and distance, i.e., 16 samples in total for each analysis. A bayesian smoother was used to analyse the soil data. This has an infinite number of parameters, one for each $\mathrm{x}$ position, thus allowing the data to determine to a very great extent the form of the curve. The relationships between the parameters are described by means of mean and covariance functions. Specifying these relationships enables the parameters, and hence the curve, to be estimated (Wecker \& Ansley 1983: Steinberg 1984; Upsdell 1985). For the soil data here, an asymptotic relationship was assumed.

Tree diameters, heights and stocking were assessed and projected on to age 28 years using the integrated stand modelling system STANDPAK (see Appendix 1 for details). An assumption was made that the predicted volume comprised 50\% edge rows ( $\mathrm{x}$ 2) and 50\% mid rows ( $x$ 5). It was also assumed that because of the small piece size, the upper SO\% of the shelterbelt trees by volume would not meet sawlog specifications and were thus categorised as pulp logs. The projected value of the shelterbelt is based on current $\log$ prices of $\$ 95$ stumpage (net return) for both categories of sawlog and $\$ 18$ for pulp logs.

\section{Results}

\section{Pasture}

Total dry matter production at the $10 \mathrm{~m}$ zone $(0.7$ tree height) for both sides of the shelterbelt was $15 \%$ greater than that produced at the "open" pasture zone (Figure 1). A significant $(P<0.05)$ trend of increasing DM production was also shown from the 40 to $200 \mathrm{~m}$ distance on both sides of the shelterbelt. However, on average the sheltered zone produced slightly less DM production than the "open" pasture zone (Table 1). Pasture species composition did not vary with distance from the shelterbelt (Table 2).

Figurel Effect of Matea shelterbelts on total dry matter production

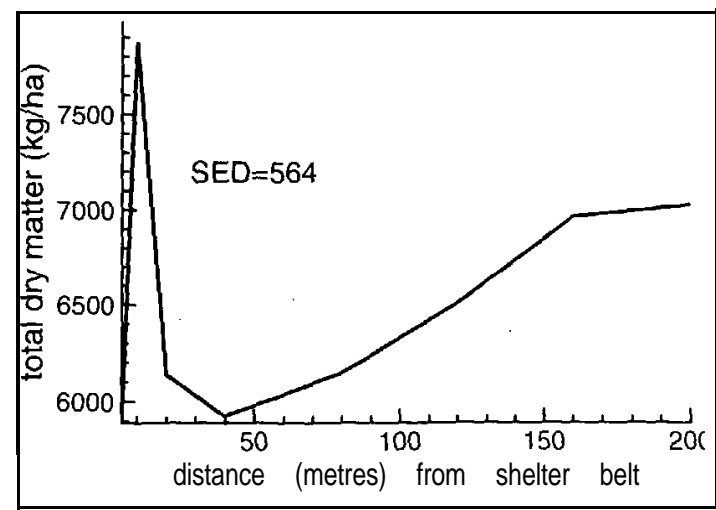

Table 1 Mean individual cut and total pasture yields (kg DM/ ha) at distances from the Matea shelterbelts

\begin{tabular}{lccccc}
\hline \multicolumn{5}{c}{ Date of at } \\
\hline Distance & 29.10 .92 & 16.12 .92 & 4.2 .93 & 25.3 .93 & Total \\
\hline $5 \mathrm{~m}$ & 1445 & 2416 & 992 & 1040 & 5892 \\
$10 \mathrm{~m}$ & 1721 & 3026 & 1830 & 1302 & 7679 \\
$20 \mathrm{~m}$ & 1271 & 2319 & 1411 & 1139 & 6140 \\
$40 \mathrm{~m}$ & 1290 & 2336 & 1292 & 1007 & 5925 \\
$80 \mathrm{~m}$ & 1016 & 2251 & 1626 & 1252 & 6146 \\
$120 \mathrm{~m}$ & 1340 & 2492 & 1508 & 1172 & 6511 \\
$160 \mathrm{~m}$ & 1264 & 2695 & 1645 & 1366 & 6972 \\
$200 \mathrm{~m}$ & 1316 & 2646 & 1769 & 1301 & 7034 \\
S. E. D. & 221 & 311 & 271 & 160 & 564 \\
\hline
\end{tabular}


Table 2 Mean herbage composition, soil and plant nutrient status of Matea site as at 29.10.92

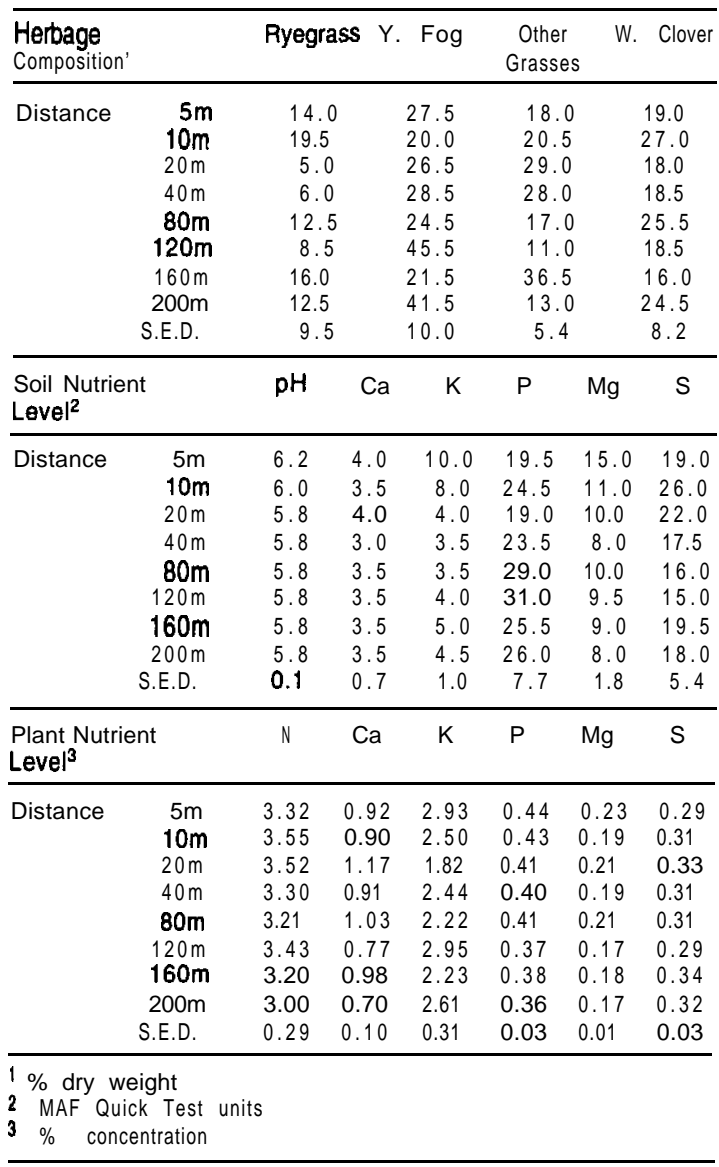

Soil $\mathrm{pH}$ and Quicktest $\mathrm{K}$ and $\mathrm{Mg}$ levels were shown to be higher close to the shelterbelt (Table 2 and Figure 2), as were herbage concentrations, particularly P. $\mathrm{Mg}$ and $\mathrm{Ca}$.

There were no effects of shelterbelt side on any of the pasture measurements.

\section{Timber}

At age 28 years the shelterbelt is predicted to have a mean tree diameter at breast height of $33.0 \mathrm{~cm}$ and a mean top height of $36.3 \mathrm{~m}$. The predicted total merchantable volume is $2300 \mathrm{~m}^{3} / \mathrm{km}$ of shelterbelt (Table 3). Because of the high final crop stocking the piece size is projected to be very small, 0.66 $\mathrm{m}^{3}$. For the purpose of projecting log grades, the shelterbelt was divided into the following two components.
Figure 2 Effect of Matea shelterbelts on soil test values

(a) $\mathrm{pH}$

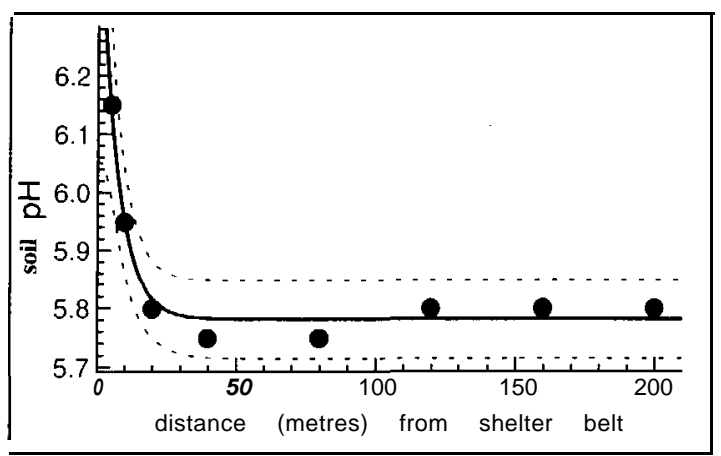

(b) $\mathrm{K}$

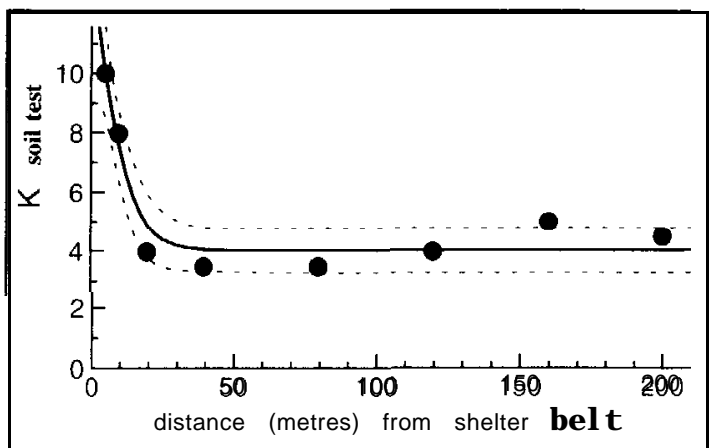

(c) $\mathrm{Mg}$

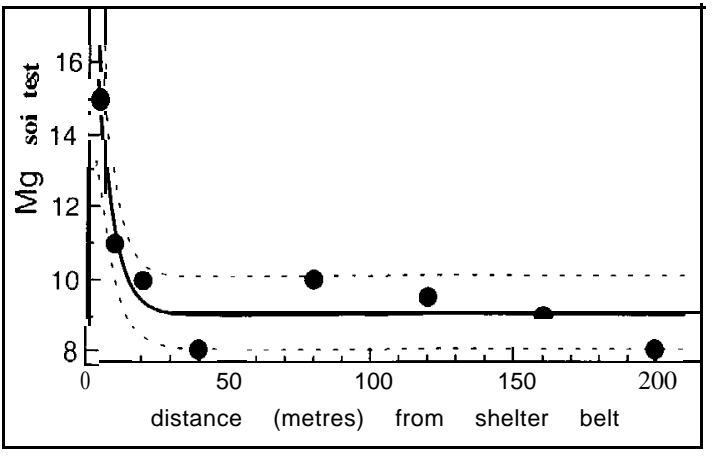

Table 3 Merchantable $\log$ volume, $\log$ grade and net returns of 7-row Matea shelterbelt

\begin{tabular}{|c|c|c|c|c|c|}
\hline Description & $\begin{array}{c}\text { Maximum } \\
\text { Branch }\end{array}$ & Log Grade & Vol./km & $\begin{array}{l}\text { Net Price } \\
\left(\$ \$ \mathrm{~m}^{3}\right)\end{array}$ & $\begin{array}{l}\text { Net Return } \\
\$ / \mathrm{km}\end{array}$ \\
\hline $\begin{array}{l}\text { Edge rows } \\
\text { (2) }\end{array}$ & $16 \mathrm{~cm}$ & $\begin{array}{l}\text { Large branched sawlogs } \\
\text { Pulp logs }\end{array}$ & $\begin{array}{l}575 \mathbf{m}^{3} \\
575 \mathbf{m}^{3}\end{array}$ & $\begin{array}{l}\$ 95 \\
\$ 18\end{array}$ & $\begin{array}{l}54,625 \\
10,350\end{array}$ \\
\hline $\begin{array}{l}\text { Mid rows } \\
\text { (5) }\end{array}$ & $6 \mathrm{~cm}$ & $\begin{array}{l}\text { Small branched small sawlogs } \\
\text { Pulp logs }\end{array}$ & $\begin{array}{l}575 \mathrm{~m}^{3} \\
575 \mathrm{~m}^{3}\end{array}$ & $\begin{array}{l}\$ 95 \\
\$ 18\end{array}$ & $\begin{array}{l}54,625 \\
10,350\end{array}$ \\
\hline Cotals & & & $00 \mathrm{~m}^{3} / \mathrm{kr}$ & & $\$ 130,000 \mathrm{~km}$ \\
\hline
\end{tabular}




\section{Edge rows}

Based on studies of mature radiata pine shelterbelts in the central North Island (Tombleson \& Inglis 1986) the two edge rows were estimated to contain a mean maximum branch size of $16 \mathrm{~cm}$, which yielded large branched sawlogs $10 \mathrm{~m}$ long. Based on current log prices they have a stumpage of $\$ 95 / \mathrm{m}^{3}$.

\section{Mid rows}

The five mid rows were estimated to contain a mean maximum branch size of $6 \mathrm{~cm}$, which yielded smallbranched, small-sized sawlogs, $10 \mathrm{~m}$ long with a stumpage of $\$ 95 / \mathrm{m}^{3}$.

Because of the small tree diameters, all logs above a height of $10 \mathrm{~m}$ were classified as pulp grade logs with a net return of $\$ 18 / \mathrm{m}^{3}$. Table 3 summarises the volume by $\log$ grades and the net returns per $\mathrm{km}$ of shelterbelt.

\section{Discussion}

The 6- and 7-row Matea shelterbelts may be better described as long narrow woodlots and as such act as solid barriers to the wind. Such shelterbelts (Cabom 1965) create a small zone of shelter close to the leeward side of the shelterbelt. McNaughton (1988) showed that beyond this "quiet" zone lies an extended region of increased turbulence. The pasture production profile of the Matea shelterbelt closely tits the wind profile associated with dense (versus permeable) shelterbelts. This result has been supported by Mr P. Smail (pers. comm.), a Canterbury farm forester with extensive experience of shelterbelt design and management, who believes that in such conditions, livestock congregate in the narrow sheltered zone immediately adjacent to the shelterbelt.

It may be possible that the associated deposits of dung and urine may have resulted in the substantial increase of pasture production at the 0.7 tree height zone.

The profile of pasture production associated with the Matea shelterbelt may also be compared with the study carried out by Radcliffe (1985) on a permeable shelterbelt located in Canterbury where it was found that pasture production peaked at 3 to 4 tree heights on the leeward side of the shelterbelt. Such shelterbelts are purposefully designed and managed to filter the wind, and as such there is less air turbulence on the leeward side. Shelter from wind of such shelterbelts is provided to a much greater area, hence livestock do not have to congregate close to the shelterbelt.

Both the Matea and Canterbury experiments showed depressed pasture production at the 0.3 tree height distance from the shelterbelt. Radcliffe (1985) suggested this could be due to a rain shadow effect, water use by the shelterbelt, cooler soils and appreciable tree shading. Root competition and excessive stock trampling are also possible explanations in the Matea shelterbelt study.

Mates, at an elevation of $690 \mathrm{~m}$, was considered to have a cold and windy climate for this region of the North Island. The orientation of the shelterbelts gave protection from the south east and north west winds. However, results indicated that orientation had little effect on DM production. Grazing management, fertiliser application or inherent soil type variation may have had more impact on DM production in this location than the shelterbelt orientation.

For timber production the shelterbelts will produce at harvest a considerable quantity of timber. Although of modest quality and value the tree crop will provide considerable returns to the landowner. It is also noted that tree size and log values could have been more than doubled with increased tree spacing and improved management, particularly with all trees being pruned to a height of $6 \mathrm{~m}$. Such an improved system would also incorporate a supplementary species to block the low draught created by the pruning. The limited data from this trial has indicated that the displacement of agriculture is more than likely to be compensated for by the considerable timber returns at harvest. The benefits of shelter for improved pasture growth have not been realised while the impact on livestock performance and animal welfare has not been measured.

A more detailed study is planned to determine whether the increased pasture production close to the shelterbelt is due to a shelter effect or nutrient transfer or a combination of these factors.

\section{ACKNOWLEDGEMENTS}

Landcorp Farming Ltd for use of the shelterbelt sites and Mr D. Elliot and Mr J. Cawston of Forest \& Woodlot Management Ltd for the supply of tree inventory data and current log prices; colleagues in AgResearch and at the NZ Forest Research Institute for constructive criticism of the paper.

\section{REFERENCES}

Cabom, J.M. 1965: Shelterbelts and windbreaks, pp 255-262. Faber and Faber.

Chevasse, C.G.R. 1982: Management of shelterbelts for wood products. NZ journal of forestry, 27(2): 189-206.

Cornforth, I.S.; Sinclair, A.G. 1984: Fertiliser recommendations for pastures and crop in New Zealand. MAF, Wellington. 
Department of Scientific \& Industrial Research 1954: General survey of the soils of North Island, NZ Soil Bureau bulletin 5.

Hawke, M.F. 1991: Pasture production and animal performance under pine agroforestry in New Zealand. Forest ecology and management 45: 109 118.

Hawke, M.F. 1992: Agroforestry Research Collaborative report, May 1992.

Holmes, C.W.; Sykes, A.R. 1984: Shelter and climatic effects on livestock. Water and Soil Misc. publication No.59, Chapter 3: 19-35.

McNaughton, K.G. 1988: Shelter: its management and promotion. Agriculture, ecosystems and environment 22/23: 17-39.

Morey, C.W. 1986: Farm forestry in New Zealand: a 1985-86 survey of farmer practice, intentions and opinions. Maclaren, P. (Ed). Proceedings of the Agroforestry Symposium. Ministry of Forestry, FRI Bulletin No. 139: 19-34.

Piggot, G.J. 1986: Methods for estimating pasture dry matter on dairy farms in Northland. Proceedings of the New Zealand Grassland Association 47: 243 247.

Radcliffe, J.E. 1985: Shelterbelt increases dryland pasture growth in Canterbury. Proceedings of the New Zealand Grasslands Association 46: 51-56.

Shelter Working Party Report 1982: Report of a Working Party Prepared for the National Research Advisory Council, and the National Water and Soil Conservation Authority.
Steinberg, D.M. 1984: Bayesian models for response surfaces I: The equivalence of several models and their relationship to smoothing splines. MRC Technical Summary Report \#2682, University of Wisconsin.

Sturrock, J.W. 1972: Aerodynamic studies of shelterbelts in New Zealand -2. Medium height to tall shelterbelts in mid Canterbury. New Zealand journal of science 15(2): 113-140.

Sturrock, J.W. 1977: Shelter and shade are worthwhile. New Zealand Journal of Agriculture 134 (5): 5.

Sturrock, J.W. 1988: Shelter: Its Management and Promotion. Agriculture, ecosystems and environment 22/23: 1 - 13.

Tombleson, J.D.; Inglis, C.S. 1986: Comparison of Radiata pine shelterbelts and plantations. Maclaren, P. (Ed). Proceedings of the Agroforestry Symposium. Ministry of Forestry, FRI Bulletin No. 139: 261-278.

Upsdell, M.P. 1985: Bayesian Inference for Functions. PhD thesis Nottingham University.

Wecker, W.E.; Ansley, C.F. 1983: The signal extraction approach to nonlinear regression and spline smoothing. Journal of the American Statistical Association 78: 81-89.

Whiteside, I.D. 1989: The 'Standpak' Stand Modelling System for Radiata Pine. In New approaches to spacing and thinning in plantation forestry, James R.N. (Ed) Proceedings of an IUFRO Symposium, FRI, Rotorua, April 1989. Ministry of Forestry FRI Bulletin No. 151.

APPENDIX I

SUMMARY OF DATA INPUTS TO STANDPAK ANALYSIS

\begin{tabular}{|c|c|c|}
\hline Age: 10 years & (actual) & \\
\hline Stocking: & stems per ha. 1360 & \\
\hline & 1 kilometre of shelterbelt & $\begin{array}{l}=2.577 \mathrm{ha} \\
=3500 \text { stems }\end{array}$ \\
\hline Pruned height: & $1.6 \mathrm{~m}$ & \\
\hline Mean top height: & $14.6 \mathrm{~m}$ & \\
\hline Site index: & $27.2 \mathrm{~m}$ & \\
\hline Mean diameter at breast height: & $26.5 \mathrm{~cm}$ & \\
\hline Basal area: & $71.0 \mathrm{~m}-\mathrm{ma}$ & \\
\hline & $237 \mathrm{~m}^{3} / \mathrm{km}$ & \\
\hline Aqe: 28 years & (predicted) & \\
\hline Mean top height: & $36.3 \mathrm{~m}$ & \\
\hline Basal area: & $94.2 \mathrm{~m}^{3} / \mathrm{ha}$ & \\
\hline Total merchantable volume/ha: & $902 \mathrm{~m}^{3}$ & \\
\hline Total merchantable volume $/ \mathrm{km}$ : & $2300 \mathrm{~m}^{3}$ & \\
\hline
\end{tabular}

